\title{
Decentralization and Innovative Behavior: The Moderating Role of Supervisor Support
}

\author{
Mahlagha Darvishmotevali
}

School of tourism and hotel management (Near East University)

\begin{tabular}{l}
\hline \\
Keywords: \\
Decentralization, \\
Innovation, Supervisor \\
Support \\
\hline Received \\
30 June 2018 \\
Received in revised form \\
O1 December 2018 \\
Accepted \\
23 December 2018 \\
\hline
\end{tabular}

Correspondence:

mahlagha.darvish@neu.edu.tr

\section{ABSTRACT}

The importance of innovative behavior for organizational effectiveness has been wildly accepted. Spite of the importance of organizational structure to promote the innovative behavior, little is known regarding the decentralized system in service industry. In addition, the role of supervisor support in such circumstances is highly significant; however, the link between decentralization, supervisory support and innovation is not particularly clear. Therefore, the current study aims to examine the impact of decentralization on employees' innovative behavior and also to investigate the moderating role of supervisor support in this process. Data was collected from 323 employees from five star hotels in North Cyprus. Structural equation modelling was applied to evaluate the measurements and model's fit. The study hypotheses were tested using LISREL 8.54. The results revealed that decentralized system has a positive impact on employees' innovative behavior. Moreover, moderating role of supervisory support in helping employees to achieve organizational innovative goals was significant. The existence of decentralization opens new opportunities for organizations and increases the innovative behavior among employees. Employees who have degree of freedom for decision-making and risk-taking within an organization are more creative, and will take the initiative to seek new and efficient ways and approaches of doing their jobs.

(C)AIMI Journals

Innovative behavior is described as the generation, promotion, and execution of new and beneficial ideas (Janssen, 2000), which results in organizational success in an unstable and ever-changing market (Barsh, Capozzi, \& Davidson, 2008). Studies on creativity and innovation have made significant progress in identifying the organizational and individual 
antecedents of innovative behavior (Anderson, Potocnik, \& Zhou, 2014; Chen, Li, \& Leung, 2016). Supervisor support (Chen, Li, \& Leung, 2016), leadership style (Rosing, Frese, \& Bausch, 2011), innovation climate (Kmieciak, Michna, \& Meczynska, 2012), and environmental dynamism (Popa, Soto-Acosta, \& Martinez-Conesa, 2017) are various examples of innovation behavior antecedents. In recent years, the decentralization of human resources management has been one of the subjects of administrative reform. Decentralization across the enterprise has become a global phenomenon affecting businesses performance. Decentralization is defined as the transferral of authority from a centre or higher levels whose jurisdiction is relatively large to a set of centres with smaller jurisdiction or lower levels (Power, 1998). It is breaking down traditional silos among business units, shifting roles and creating possibilities for new syntheses. Lee, Min, and Lee (2016) emphasized the impacts of organizational structure on open innovation and demonstrated that a decentralized system encourages opens innovation (both inbound and outbound). They suggest that a decentralizeddecision making system is a means to unleash open innovation (Lee, Min, \& Lee, 2016).

Although previous scholars (Bos-Nehles, Bondarouk \& Nijenhuis, 2017; Popa, SotoAcosta, \& Martinez-Conesa, 2017) have focused on the antecedents and predictors of innovation behavior, the process through which DE impacts employees' IB is, however, relatively novel and poorly understood (Popa et al., 2017). In particular, little is known about the idea generation, idea promotion, and idea realization effects of decentralized structure. In order to fill this gap, this research adopts a more focused view on the impacts of decentralization on innovative behavior in hotel context. On the other hand, researchers suggest that supervisor support is vital to motivate employees for showing innovative behavior (Anderson et al., 2014). If supervisors demonstrate that they care about their employees' security, well-being and value their assistance, this will consequently enhance their innovative behaviors (Anderson et al., 2014; 2004). Frontline managers and supervisors have more ability to interpret organization policies, make daily operational decisions, implement training processes and assert their influence within the organization. Although the importance of the role of supervisor support in such circumstances is highly significant, the link between decentralization, supervisory support and innovation is not particularly clear (Popa et al., 2017). Hence in order to address this gap, the current paper tries to examine the interaction effect of decentralization and supervisor support on organizational innovation in the service industry.

Consequently, the findings of the present study theoretically contribute to the all three main variables in the literature as follows: firstly, by examining the impact of decentralization on employees' innovative behavior; secondly, by testing the interactive effect of supervisor support and decentralized structure on innovative behavior. In practical terms, the findings of the study can be highly effective and useful for managers and researches in the hospitality industry. Thus, the current study has two main objectives: decentralization positively impacts innovative behavior (idea generation, idea promotion, \& idea realization) among hotel employees and also supervisor support moderates the positive impact of decentralization on innovative behavior. Figure 1 depicts the research model. 


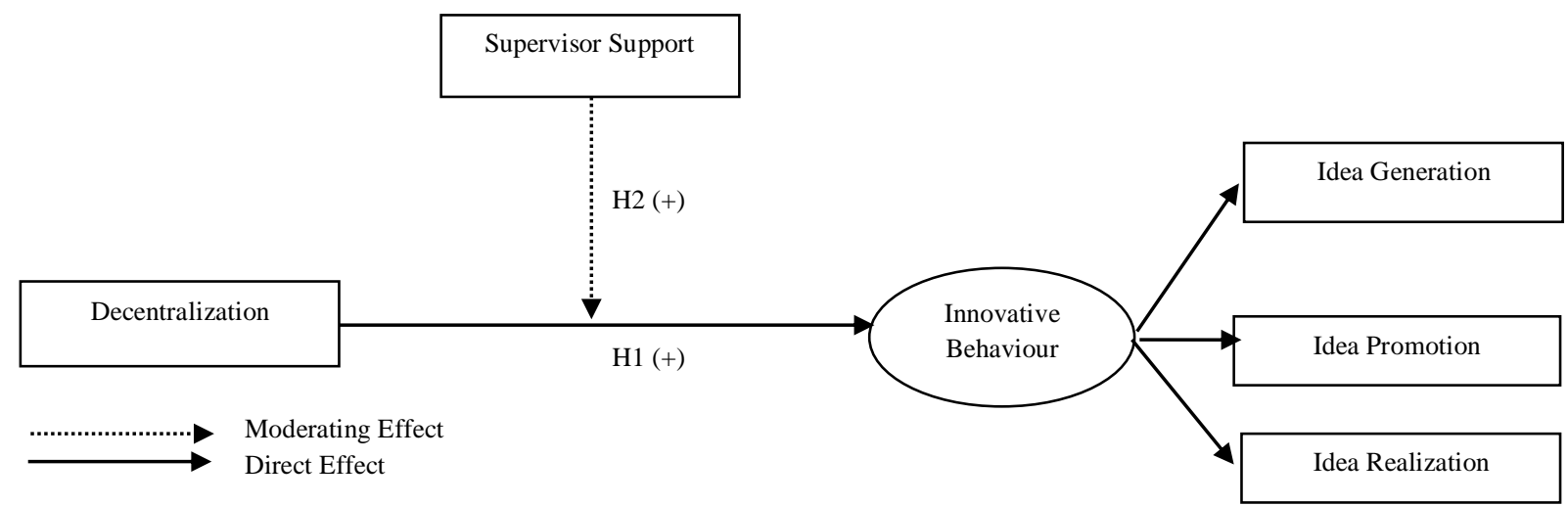

Figure 1. Moderating model of innovative behavior

Decentralization is a type of organizational structure in which decision-making responsibilities is delegated to the low levels managers and employees. Decentralization gives more power and autonomy to lower level staff to make decisions. A decentralized structure shows more control and a bottom-to-top flow of ideas, comments and decisions. Under decentralization, all members can act more quickly to make a decisions and solve problems and control the situation. Decentralization offers several advantages for those organizations, which aim to have competitive strategies. Actually structure of an organization should follow the strategy of the organization. If the organization follows innovation strategy, the organizational structure must be organic. It requires losing structure, low formalization, low specialization, and more decentralization (Robbins, Judge, \& Breward, 2003). In the following, we will discuss regarding decentralization from management and employees' perspective.

From the management perspective we can mention to the relieving the responsibilities, more efficient decision-making, ease of expansion, facilitates growth, better control, flexibility, human resource development, work specialization and high levels of decision.

Decentralizing takes some of the responsibilities from the managers and gives to the lower levels in the organization. When managers allow others to decide for daily operation within an organization, may spend more time on more serious issues, such as planning for developing organization or meeting with significant customers, focusing on strategy and high level decisions. Employees can make a decision and react quickly to situations where quick decision and action can mean the difference between gaining and losing a customer. Decentralisation enables the employees to perform by their maximum potential, as well as promotes a sense of competition among them, which motives them towards growth of the enterprise too. Decentralization can facilitate the process of expansion for a growing business. Through decentralization all members can react more quickly to the particular needs of the area as an independent party. Under strong decentralization structure employees may improve their personal sources such as self- efficacy or self-esteem and more important innovative abilities.

In order to stay competitive in today's complex market, organizations must show immediate reaction and make a decision very quickly. This requires a complete flexible system. A decentralized system creates a flexible environment for lower levels managers and employees to interpret different conditions and make suitable and timely decisions and build competitive strategies. Through decentralization, the top managers' excessive workload will decrease, 
which help them to save their time and focus on core and important issues, making appropriate programs and providing strategic direction for general important decisions, innovation, growth, and further development. Decentralized system provides opportunities for employees at each level to develop their skills and expertise, as well as top level managers and executives become aware regarding the actual potential and capacity of the lower level employees and managers, and can better delegate duties on them.

Empowering employees, develops initiative among employees, develops managerial talent for the future, quick decision making, and facilitate effective marketing are some example resulting of decentralization from employees' perspective. Under a perfect decentralized structure, employees can improve their skills by handling different duties independently. This can enhance their information, knowledge, and experiences at all levels. It also provides qualified manpower for fulfilling the top positions through promotions. Employees can be more empowered by having more autonomy to react in special situation and make appropriate decisions, and giving them a sense of importance, as well as allows them to use of their knowledge, abilities and experience to gain and implement their own ideas and strategies. Decentralisation helps the managers at the lower levels to take all those decisions, which are for the betterment of organization on their own and to develop solutions for solving the various problems they face. This helps in enhancing confidence and self-reliance among the employees. Decentralization promotes independent and fast decision making process by employees as they are constantly touch with all activities within an organization and directly contact with customers. In decentralized organization all members from top to down are sharing the decision making powers. They have different levels of autonomy and delegation. Delegation and freedom of action promote team working among employees. In this condition employees and managers may complete each other as a team towards achieving organizational goals.

Decentralized structure allows employees to work in terms of their decision and they are directly responsible for their actions within an organization, they are thus more cautious what to do. Managers' effort to make organization more flexible, active and responsive has opened a recent trend toward decentralized decision making by lower- level managers, who are closer to the action and generally have more detailed information about different issues within an organization.

\section{Literature Review and Hypothesis Development Innovative Behavior}

The significant role of innovation for organizational achievement and success is strongly accepted. Innovative behavior is explained as introduction and application of novel opinions, products, processes, and procedures to an individual's job roles, work units, or organizations. Scott and Bruce (1994) defined employees' innovative behaviors as the generation, promotion, and execution of new and valuable ideas. Innovative behavior can be conducted either by a member or groups of members within the organization.

The terms creativity and innovation are largely used interchangeably in different studies, and the distinction between these two concepts may be more one of emphasis rather than substance (West \& Farr, 1990). However, a consensus regarding the terms' definitions has recently emerged; creativity is related to the production of new and practical ideas (Mumford, 
Scott, Gaddis, \& Strange, 2002), whereas innovation is concerned with the production or adoption of valuable ideas and implementation of ideas (Kanter, 1988). Innovation is the process of redesigning of a product or process from outside the organization. Researchers who are working on innovation topic have explicitly accepted that idea generation is just one step of a multistep process on which different social factors are influential (Kanter, 1988). Based on this view, employees' innovation starts with issue or problems recognition as well as idea generation or solutions, either new or adapted. During the second step of this process, innovative employees seek sponsorship for ideas and try to create an alliance of supporters and fans for this idea. Eventually, in the next (third) step of the process, the employees complete their novel ideas by generating models that can be seen, touched, feasible or experienced, and subsequently be diffused or mass-produced (Kanter, 1988). Therefore, innovation is considered to be a multi-step process, with different variety activities and behaviors at each step. Since innovation is featured by permanent activities rather than discrete, sequential steps (Schroeder, Van de Ven, Scudder, \& Polley, 1989), employees can be expected to be involved in every combination of these stages at any time.

\section{Decentralization}

According to the business dictionary, decentralization is described as a transfer of decisionmaking power and the assignment of accountability and responsibility for results. It is accompanied by the delegation of commensurate authority to individuals or units at all levels of an organization, even those far removed from headquarters or other centers of power.

Decentralization is a broad concept, as it is the extent to which authority is delegated from one level or one unit of the organization to another (Mosley \& Pietri, 2014). Decentralization will cause a delegation of power downwards, to the regular employees (Kralewski, 2012). Decentralization is described as a shift in the responsibility for planning, management, and the raising and allocation of resources from central management to semi-autonomous authorities, functional authorities or voluntary organizations (Rondinelli \& Nellis, 1986). Decentralization can be described in similar dimensions to centralization, by proposing two approaches to decentralization, which are vertical degradation and horizontal diffusion. The first approach of vertical degradation happens when authority is transferred from one level of organization, typically from higher levels to lower levels. The second approach of decentralization refers to horizontal diffusion, which explains the movement of authority from the centre, such as central management, to the periphery, such as the supervision sectors. A number of studies have been conducted to examine vertical degradation in substantive policy fields such as health and welfare reform (Grodzins \& Elazar, 1974; Jennings \& Ewalt, 1999; Tolbert \& Zucker, 1983). Administrative decentralization is another type of decentralization which refers to the redistribution of power, responsibility and fiscal resources to provide public services between different levels of an organization. Administrative decentralization involves the full or partial transfer of an array of functional responsibilities to the lower levels, such as supervisors and frontline managers. There are three main types of administrative decentralization deconcentration, delegation and devolution - each of which has different characteristics. 


\section{Decentralization and Innovative Behavior}

Empirical studies to assess the effect of decentralization on outcomes such as economic growth, innovation, or governance and corruption have shown mixed results (Garman, Haggard, \& Willis, 2001; Martinez-Vazquez, 2003; Rodríguez-Pose \& Ezcurra, 2011; Taylor, 2007). Are service industries with decentralized management oriented more effective at developing long-term innovation than companies with centralized management? Ritzen and Soete (2011) claimed that the decentralization of innovation policy, if properly managed, can stimulate healthy competition which in turn can improve aggregate innovation performance. Liu, Martineau, Chen, Zhan, and Tang (2006) examined the role of decentralization to improve the human resource management in health departments. The results demonstrated that decentralization can give better control to the health service managers to manage their employees. In some cases, it may lead to improved human resources outcomes and eventually, better health services. Madanoglu, Altinay, and Wang (2016) investigated the impact of family involvement on entrepreneurial behaviors via decentralization. The results contributed to entrepreneurship literature by providing a clear explanation of how a decision-making mechanism such as decentralization impacts innovation. The findings demonstrated that decentralization is a significant antecedent of innovation and the risk-taking process. Lee et al. (2016) attempted to provide a better understanding of open innovation within the context of decentralization by examining 2,811 projects. The analysis results revealed that the decentralization of decision-making encourages both inbound and outbound open innovation.

In this paper, it is proposed that decentralization affords companies significant opportunities. Decentralization helps in innovation in that it allows employees with different skills and different thoughts to bring together different products and technologies to satisfy the unmet needs of patients or customers. Thus:

$\mathbf{H}_{1}$ : Decentralization positively impacts the innovative behavior among employees.

\section{Supervisor Support}

A supervisor is defined as an individual who is in the first-line management to control and regulate employees in their works. Supervisors monitor employees' performance of delegated responsibilities and tasks. Supervisors affect hiring, punishing, rewarding, changing, and other activities which are associated with employees. Supervisors give organizational instructions to employees and are responsible for the operations, productivity, and overall performance of a group of employees. Supervisor as a manager-like role has an important and significant effect in developing positive and safety attitudes, work training, up-to-date working methods and strategies, and identifying unpleasant actions in the workplace (Miedema, 2015). Supervisors provide a supportive relationship, which create resources such as sharing information, emotional empathy/sympathy or tangible/intangible cooperation and assistance (House, 2003). Supervisors have very significant role to create a safe workplace for employees, since they are close to the actual work being done and can identify and solve employees' safety and security concerns. House (2003) argued that supervisory support is divided into four sources: Task support, relation support, evaluation support, and informational support. Task support refers to the preparation equipment, latest technology, money, time and environmental modification. Relation support are those kind of support relating to the esteem, trust, affection, interest, 
listening. Evaluation support refers to the verification, affirmation, feedback, fair comparison. The informational support refers to the advice, suggestions, and guidance. Supervisors through these four main sources of support are able to enhance employees' capacity to cope with any problems and stress in the workplace.

\section{Supervisor Support as a Moderator}

On the other hand, significant issues can be observed in the process of supervision in decentralized structures. Supervisors are responsible for monitoring the quality of the services and assessing employee's needs. In accordance with the significant role of leadership (Redmond, Mumford, \& Teach, 1993), supervisor's support has been shown to be an effective antecedent of employees' innovative behavior and creativity (Mumford, Scott, Gaddis, \& Strange, 2002; Rosing, Frese, \& Bausch, 2011). According to the Leader - Member Exchange (LMX) theory (Dienesch \& Liden, 1986), the relationship between leaders and members in an organization develops over time through a series of observations, try-outs, interactions and conversations. When a manager or supervisor is close to the employees, they will consider each other "in-group"; however, the other employees will become "out-group". When supervisors and employees have closer relationships, employees will tend to demonstrate better performance and creativity (Graen, Novak, \& Sommerkamp, 1982).

Studies show that "in-group" members are generally $20 \%$ more efficient in terms of job performance and 50\% more satisfied with their jobs than "out-group" members (Mayfield \& Mayfield, 1998). Alvesson and Sveningsson (2003) emphasized the important role of supervisors by demonstrating that leaders are pivotal in determining the direction and overall guidelines for organizational performance, because innovative ideas require leadership in the form of advocates. The results show that middle managers play the role of 'knowledge-transfer agents' (Richards \& Duxbury, 2014) by establishing a context that facilitates individual knowledge acquisition and sharing. In such a context, employees would be encouraged to accumulate, use or even extend their knowledge for the purpose of improving processes and innovation. In a decentralized organization, middle and lower levels of management make broader, more important decisions about their units (Mosley \& Pietri, 2014). Bos-Nehles et al. (2017) in a comprehensive qualitative research study, showed the power and ability of publicsector supervisors to lead and encourage employees in innovative behaviors. On the downside, implementation failures and the shortage of essential innovation projects seem to be the consequences of loosely coupled bottom-up and top-down innovation projects and decentralization that need situational leadership, which stress network activities and lobbying with public managers.

Organizations' managers and supervisors can positively influence employees' motivation, satisfaction, and can create a positive atmosphere, which encourages innovative behavior among employees (Damanpour \& Schneider, 2009). In the present study, it is hypothesized that in decentralized systems, frontline managers and supervisors have more ability to interpret organization policies, make daily operational decisions, implement effective training processes and assert their influence within the organization. This can be beneficial and effective for motivating employees to increase their job performance. Thus: 
$\mathbf{H}_{2}$ : Supervisor support moderates the positive impact of decentralization on innovative behavior.

\section{Method}

The research was conducted in five-star hotels located in North Cyprus. For collecting data, the researchers contacted the hotels' director of public relations with the letter of authorization requesting to conduct the study. In partnership with one of the researchers, responsible personnel within the hotels distributed questionnaires among the target groups and completed questionnaires were returned. Ultimately, 323 samples were selected. Thirty-eight percent of the sample was between the ages of 28-37, and only $2.2 \%$ was the aged 58 or above. In terms of gender, the sample included $61 \%$ males and $39 \%$ females. In terms of education, approximately $41 \%$ of the respondents had a vocational school diploma and $36 \%$ had a bachelor's degree. Fifty- six percent of respondents were single or divorced and the rest (44\%) were married. Four items were measured for supervisor support developed by Peeters, Buunk, and Schaufeli (1995), decentralization used seven items developed by Ghoshal (1987), and nine items were used for innovative behavior, as developed by Janssen (2000). Responses were based on 5-point Likert type scale, ranging from $1=$ strongly disagree to $5=$ strongly agree. Structural equation modelling was applied to evaluate the model's fit and test the study hypotheses using LISREL 8.54. Table 1 presents respondents' demographic information

Table 1

Respondents' Demographic Information (sample size $=323$ )

\begin{tabular}{llcc}
\hline Item & Response & Number of Response & Percentage \\
\hline Gender & Male & 197 & 61 \\
Age group & Female & 126 & 39 \\
& $18-27$ & 76 & 23.5 \\
& $28-37$ & 124 & 38.4 \\
& $38-47$ & 85 & 26.3 \\
Education & $48-57$ & 31 & 9.6 \\
& 58 and above & 7 & 2.2 \\
& Primary school & - & - \\
& High school & 68 & 21.1 \\
Tenure & Vocational school & 132 & 40.9 \\
& Bachelor degree & 117 & 36.2 \\
& Master or Ph.D & 6 & 1.9 \\
& below 1 year & 46 & 46.4 \\
Marital Status & $1-5$ & 150 & 32.2 \\
& 6-10 & 104 & 6.5 \\
& $11-15$ & 21 & 0.6 \\
\end{tabular}

\section{Results}

In the first step of analysis, the construct validity (convergent and discriminant) and reliability of the all study items were tested. Convergent and discriminant validity were assessment by Average Variance Extracted (AVE) and Composite Reliability (CR) based on the cut-off level (CR>0.70; AVE>0.50; CR>AVE) (Hair, Black, Babin, \& Anderson, 2010). The findings show that $\mathrm{CR}$ and AVE for all variables were greater than .70 and .50, respectively. Furthermore, the Cronbach's alpha coefficient for each variable was suitable based on the cut-off level (see Table 2). 
Table 2

Items, Factor Loadings and Construct Validity Results

\begin{tabular}{|c|c|c|c|c|c|c|c|c|}
\hline Items & $\begin{array}{l}\text { Standardized } \\
\text { Loadings }\end{array}$ & $\begin{array}{c}\mathrm{t}- \\
\text { Value }\end{array}$ & AVE & $\mathrm{CR}$ & $\mathrm{C} \alpha$ & MSV & ASV & $\sqrt{ } \mathrm{AVE}$ \\
\hline \multicolumn{9}{|l|}{ Supervisor Support (Peeter, Buunk, \& Schaufeli 1995) } \\
\hline My supervisor shows her/him satisfaction of my performance. & 0.79 & 17.37 & & & & & & \\
\hline My supervisor shows that he/she likes me & 0.73 & 17.36 & & & & & & \\
\hline My supervisor helps me how to do my duties & 0.76 & 17.82 & & & & & & \\
\hline My supervisor guides me how to manage my job & 0.76 & 17.93 & & & & & & \\
\hline Decentralization (Ghoshal, 1987) & & & 0.68 & 0.90 & 0.89 & 0.10 & 0.06 & 0.94 \\
\hline Our hotel has own market strategy. & 0.87 & 22.48 & & & & & & \\
\hline Our hotel goals are driven primarily by the local market satisfaction. & 0.83 & 21.18 & & & & & & \\
\hline Our hotel build yearly performance targets. & 0.76 & 17.15 & & & & & & \\
\hline Our hotel know the local market better. & 0.80 & 20.83 & & & & & & \\
\hline $\begin{array}{l}\text { Our annual business strategies have made according to the local } \\
\text { market condition. }\end{array}$ & 0.79 & 19.88 & & & & & & \\
\hline $\begin{array}{l}\text { Our hotel can adjust the market scheme any time to meet the market } \\
\text { needs. }\end{array}$ & 0.78 & 17.77 & & & & & & \\
\hline $\begin{array}{l}\text { Our hotel monitor market movement and make } \\
\text { effective market plan }\end{array}$ & 0.71 & 15.65 & & & & & & \\
\hline Innovative Behavior (Janssen (2000) & & & 0.75 & 0.94 & 0.78 & 0.16 & 0.12 & 0.86 \\
\hline Idea Generation & & & 0.78 & 0.69 & 0.68 & & & \\
\hline Searching for new methods, techniques or instruments. & 0.72 & 17.72 & & & & & & \\
\hline Creating novel ideas for significant issues. & 0.62 & 17.82 & & & & & & \\
\hline Generating new solutions for problems and possible challenges. & 0.75 & 17.80 & & & & & & \\
\hline Idea Promotion & & & 0.66 & 0.81 & 0.77 & & & \\
\hline Mobilizing support for innovative plans & 0.72 & 17.53 & & & & & & \\
\hline Acquiring approval for innovative plans & 0.79 & 18.10 & & & & & & \\
\hline creating enthusiastic team for innovative plans & 0.85 & 17.72 & & & & & & \\
\hline Idea Realization & & & 0.73 & 0.72 & 0.71 & & & \\
\hline Transforming innovative ideas into useful applications. & 0.57 & 17.82 & & & & & & \\
\hline $\begin{array}{l}\text { Introducing innovative ideas into the work environment in a } \\
\text { systematic way. }\end{array}$ & 0.70 & 17.80 & & & & & & \\
\hline Evaluating the utility of innovative ideas & 0.72 & 17.72 & & & & & & \\
\hline
\end{tabular}

Note: all items are measured by a 5-point scale.

Common method bias (CMB) presents a potentially significant threat of bias in social research (Podsakoff, MacKenzie, Lee, \& Podsakoff, 2003). The possibility of creating CMB can be reduced by using different procedural and statistical remedies, both of which were used in the present study. With regards to the procedure remedies, it involved insisting on respondent anonymity, face validity, and placing demographic information at the end of the questionnaire, based on statistical remedies, we conducted a serious confirmatory factor analyses (CFA) approach to Herman's one-factor test. The results of a set of fit indices demonstrated that the hypothesized 5-factor model, including decentralization, supervisor support and innovative behavior (IG, IP, and IR) fit the data well (see Table 3). The structural model tested the direct effect and the interaction effect of supervisor support and decentralization on innovative behavior. Overall, the procedures and statistical procedures together provide strong evidence that these findings are not seriously threatened by common method bias. 
Table 3

Structural Model Result

\begin{tabular}{lllllllll}
\hline Model & $\chi 2 / d f$ & GFI & AGFI & CFI & NNFI & RFI & SRMR & RMSEA \\
\hline Research Model & 1.86 & .91 & .92 & .93 & .94 & .92 & .04 & .05
\end{tabular}

NOTE: GFI = Goodness-of-Fit- Index; AGFI = Adjusted Goodness of Fit Index; CFI = Comparative Fit Index; NNFI = Non-Normed Fit Index; RFI= Relative Fit Index; SRMR = Standardized Root Mean Square Residual; RMSEA = Root Mean Square Error of Approximation.

The composite scores for all measurements were computed by averaging the scores of the items related to each latent variable. Table 4 shows the latent variables' means, standard deviation (SD), and their inter-correlation. Innovative behavior was correlated significantly with age $(\mathrm{r}=-.20, p<.001)$, gender $(\mathrm{r}=-.15, p<.001)$, education $(\mathrm{r}=.16, p<.001)$, tenure $(\mathrm{r}$ $=-.13, p<.05)$, supervisor support $(\mathrm{r}=.62, p<.001)$, and decentralization $(\mathrm{r}=.53, p<.001)$.

Table 4

Means, SD, Ca and Correlations

\begin{tabular}{|c|c|c|c|c|c|c|c|c|c|c|c|c|}
\hline Variables & $M$ & $S D$ & 1 & 2 & 3 & 4 & 5 & 6 & 7 & 8 & 9 & 10 \\
\hline 1- Age & 2.28 & 1.00 & 1.00 & & & & & & & & & \\
\hline 2- Gender & .39 & .49 & -.02 & 1.00 & & & & & & & & \\
\hline 3- Edu. & 3.19 & .78 & $-.18 *$ & .07 & 1.00 & & & & & & & \\
\hline 4- Tenure & 2.33 & .82 & $.22 *$ & -.02 & $-.12 * *$ & 1.00 & & & & & & \\
\hline 5- SS & 4.24 & .63 & $-.19 *$ & $-.17 *$ & $.11^{* * *}$ & $-.12 * *$ & 1.00 & & & & & \\
\hline 6- DE & 3.99 & .73 & -.11 & -.07 & .07 & -.08 & $.46^{*}$ & 1.00 & & & & \\
\hline 7- IG & 4.26 & .59 & $-.15^{*}$ & -.08 & .11 & -.03 & $.47 *$ & $.44 *$ & 1.00 & & & \\
\hline 8- IP & 4.16 & .70 & $-.16^{*}$ & $-.17 *$ & $.16^{*}$ & $-.12 * *$ & $.59 *$ & $.47 *$ & $.57 *$ & 1.00 & & \\
\hline 9- IR & 4.40 & .57 & $-.17 *$ & -.10 & $.11^{* *}$ & $-.15^{*}$ & $.41^{*}$ & $.35^{*}$ & $.33^{*}$ & $.42 *$ & 1.00 & \\
\hline 10-IB & 4.27 & .49 & $-.20 *$ & $-.15 *$ & $.16^{*}$ & $-.13 * *$ & $.62 *$ & $.53 *$ & $.79 *$ & $.86^{*}$ & $.72 *$ & 1.00 \\
\hline
\end{tabular}

Multiple moderated regression analysis (Zheng, Diaz, Tang, \& Tang, 2014) was used to test $\mathrm{H}_{2}$, which proposed that supervisor support strengthens the positive impact of decentralization on innovative behavior. To test $\mathrm{H}_{2}$, age, education and tenure were entered in step 1, decentralization and supervisor support in step 2, and the interaction (decentralization * supervisor support) in step 3. The results shown in Table 5 demonstrate the positive relationship between $\mathrm{DE}(\beta=.51, p<.001)$, supervisor support $(\beta=.62, p<.001)$ and innovative behavior. The results show that the interaction effect of decentralization * supervisor support $(\beta=.77, p<.001)$ on innovative behavior are significant, suggesting that supervisor support strengthens the positive affect of DE on IB.

Table 5

Interaction Effect

\begin{tabular}{|c|c|c|c|c|c|c|}
\hline \multicolumn{7}{|c|}{ Innovative Behavior } \\
\hline Variables & $\beta$ & $t$ & $\beta$ & $t$ & $\beta$ & $t$ \\
\hline \multicolumn{7}{|c|}{ Step1 (Control variables) } \\
\hline Age & $-.17 * *$ & -2.97 & $-.12 * *$ & -2.53 & $-.89 * *$ & -1.94 \\
\hline Education & $.12 * * *$ & 2.22 & $.10 * *$ & 2.03 & .08 & 1.85 \\
\hline Tenure & -.07 & -1.34 & -.05 & -1.03 & -.03 & -.78 \\
\hline \multicolumn{7}{|l|}{ Step2 (Direct Effect) } \\
\hline Decentralization & & & $.51 *$ & 10.89 & -.18 & -1.88 \\
\hline Supervisor Support & & & $.62 *$ & 14.31 & $.32 *$ & 4.74 \\
\hline \multicolumn{7}{|c|}{ Step 3 (Interaction Effect) } \\
\hline $\mathrm{DE} * \mathrm{SS}$ & & & & & $.77 *$ & 8.10 \\
\hline$F$ & & $7.21 *$ & $37.03^{*}$ & & & $48.77 *$ \\
\hline$R^{2}$ at each step & & .06 & .32 & & & .43 \\
\hline$\triangle^{R^{2}}$ & & & .26 & & & .11 \\
\hline
\end{tabular}

Note: $* \mathrm{P}<.001, * * \mathrm{P}<.01, * * * \mathrm{P}<.05$. DE: Decentralization, SS: Supervisor Support. 


\section{Discussion and Conclusion}

The present paper describes a case study which was conducted in five star hotels in North Cyprus to test whether decentralization has resulted in enhanced innovation, and also the moderating role of supervisor support in this process. These results from the research provide support for the hypotheses.

The findings revealed that decentralization positively impact on innovative behavior, which coincides with the findings of Lin and Chen (2013), Madanoglu et al. (2016), and Popa et al. (2017). The existence of decentralization opens new opportunities for organizations and increases the innovative behavior among employees. Organization decentralization is perceived as an essential institutional foundation for promoting long-run innovation. Decentralized companies are widely known to be agile, competitive, predictable, and well-structured to achieve organizational innovation. The benefits of the decentralization of innovation policies stem from the potential for organizations to identify strengths and opportunities, to respond to environmental changes, and to mobilize intra-firm networking and public-private partnerships, thus improving their ability to overcome systemic inefficiencies and information asymmetries. Decentralisation is characterized by empowerment and participation. In a decentralized system, the more focus is on the lateral relationship rather than command or force. Evidence shows that such system generally tends to be easier to implement in private sectors than in the public sectors, where there are more demands for the accountability of performance, regularity of procedures and unity of treatment (Ezigbo, 2012). One of the significant advantages of decentralized structure refers to the bottom-up flow of information. The bottom-up flow allows lower-level staff to better inform regarding any decision-making processes. For instance, if an experienced technician at the lower level of company knows how to improve the productions' efficiency, the bottom-to-top flow of information can enable this knowledge to pass up to the top level managers.

Furthermore, supervisor support strengthens the positive impact of decentralization on innovative behavior. The above-mentioned findings are rooted in the leader-member exchange (LMX) theory (Graen \& Uhl-Bien, 1995), which asserts that those subordinates who have 'high-quality' relationships with their supervisors are given more resources, more decisionmaking abilities and autonomy in return for high engagement. Fresh considerations and experimenting with novel ideas require extra time, resources and autonomy in the workplace. Greater resources and support from a supervisor increase the likelihood that innovative work behavior will be successful (Yuan \& Woodman, 2010). Supervisors tend to assess employees, whom they trust more positively, leading to the overall perception that new ideas that originate from trusted and respected subordinates are meaningful and significant. These employees are perceived as more potent and effective because of their access to important information and resources held by their supervisor (Wang, Fang, Qureshi, \& Janssen, 2015). At the same time, in a decentralized structure where employees have a degree of freedom for decision-making and risk-taking, if they are supported by managers and supervisors, their creative behaviors will increase. Therefore, it is concluded that the interactive effect of decentralization and supervisor support can be an effective combination for significantly increasing the creative behaviors among employees. 


\section{Theoretical Contribution}

In spite of growing interest in analyzing decentralization, there has been less focus on understanding how DE affects innovative behavior in workplaces. These findings theoretically contribute to the related literature of all three study variables (decentralization, innovative behavior and supervisor support) by examining their causal relationship using data from five star hotels in North Cyprus.

The results of the study contribute to the literature on DE and innovation by examining the direct impact of DE on three dimensions of innovative behavior (Bos-Nehles et al., 2017; Popa et al., 2017). These results show that a decentralized structure in the hospitality industry can lead to innovation within organizations. The results revealed that affording opportunities and a degree of freedom to employees in the workplace could create a situation that is conductive to generating and implementing novel ideas and creativity.

The second part of this study demonstrates and confirms the important role of supervisor support in a different structure. There have been numerous studies regarding the important role of supervisor support in encouraging employees to reach organizational goals; however, in the context of decentralization, it is still not well known or understood (Popa et al., 2017). The current paper evaluates the moderating role of supervisor support on the impact of decentralization on innovation. The findings contribute to the related literature on all three study variables by demonstrating the significant role of supervisor support in increasing innovative behavior under decentralized circumstances.

\section{Managerial Implication}

In the dynamic and complex environment, the organizational structure can play a highly significant role in developing the climate for creativity and innovation (Van der Sluis, 2004). Managers of large and modern organizations who are conducted a variety of activities and issues may not be successful without delegating a part of the management's mandate to lowerlevel managers and creating decentralization of the activities. In an unstable environment, mechanistic organizational design is not a suitable strategy for industries. Innovation capability in an uncertain and changing environment is more compatible with an organic design of the organization (Daft, 2015). Innovative decisions in an era of decentralization as an indicator of organic organizational design will be undertaken by the regular employees, providing impetus to the rapid development of companies. Organizations should focus more on employees, supporting them with training system, suggesting ethical standards and giving freedom to make decisions and assume their own responsibility. Employees and teams should have easy access to information in order to use it for the benefit of the organization. Smart decentralization requires building flexible, multilevel organizational systems which allow for asymmetric decentralization across policy instruments and employees that are well advised on how to experiment with new tools to improve internal coordination in innovation policy. Only such an approach will prevent duplication, ensure consistency and, more importantly, will provide a precise analysis of the costs incurred by the company (Kralewski, 2012). This forces a different approach to the management of the organization, in which the employees will set goals and innovation strategy. 
The results certainly reveal the significant role of supervisor support in helping employees to reach to organizational innovative goals under a decentralized system. However, the lack of capable and experienced low-level managers and supervisors naturally limits the scope of decentralization and the delegation of authority. In a situation where the organizations face a shortage of experienced and capable supervisors, the most effective programs can be educational measures, through which the specialized abilities and professional skills of managers will grow and develop. Higher level managers within the organization need to develop programs for the development of their own low-level managers, whose delegation of authority and organizational cultures can be part of this program.

\section{Limitations and Recommendations}

The current explanatory research was conducted in the context of hotel in North Cyprus, which may limit the generalizability of the results; thus, it is recommended that future research considers other sectors or subsectors of the society. The data was collected at one-time point, which does not enable the researchers to determine when the decision to decentralize was made; therefore, prospective researches should collect the data longitudinally. This research used observed variables; future studies can examine the variables' components to provide a deeper understanding of the relation between the variables.

\section{References}

Alvesson, M., \& Sveningsson, S. (2003). Good visions, bad micro-management and ugly ambiguity: Contradictions of (non-) leadership in a knowledge-intensive organization. Organization Studies, 24, 961-988.

Anderson, N., Potocnik, K., \& Zhou, J. (2014). Innovation and creativity in organizations:Astateof- the-science review, prospective commentary, and guiding framework. Journal of Management, 40, 1297-1333.

Barsh, J., Capozzi, M., \& Davidson, J. (2008). Leadership and innovation. McKinseyQuarterly, 1, 36-47.

Bos-Nehles, A., Bondarouk, T., \& Nijenhuis, K. (2017). Innovative work behavior in knowledge-intensive public sector organizations: The case of supervisors in the Netherlands fire services. The International Journal of Human Resource Management, 28(2), 379-398.

Chen, T., Li, F., \& Leung, K. (2016). When does supervisor support encourage innovative behavior? Opposite moderating effects of general self-efficacy and internal locus of control. Personnel Psychology, 69(1), 123-158.

Daft, R. L. (2015). Organization theory and design. Hamshire, UK: Cengage learning.

Damanpour, F., \& Schneider, M. (2009). Characteristics of innovation and innovation adoption in public organizations: Assessing the role of managers. Journal of Public Administration Research and Theory, 19, 495-522.

Dienesch, R., \& Liden, R. (1986). Leader-member exchange model of leadership: A critique and further development [J]. Academy of Management Review , 11: 618-634.

Ezigbo, C. (2012). Achieve organisational effectiveness by decentralisation. European Journal of Business and Management, $4(20), 125-135$.

Garman, C., Haggard, S., \& Willis, E. (2001). Fiscal decentralization: A political theory with Latin American cases. World Politics, 53, 205-236.

Ghoshal, S. (1987). Global strategy: An organizing framework. Strategic Management Journal, 8(5), 425-440.

Grodzins, M., \& Elazar, D. J. (1974). Centralization and decentralization in the American Federal system. In A. Robert Goldwin (Ed.), Nation of states, 2nd ed (1-24). Chicago: Rand McNally.

Graen, G. B., \& Uhl-Bien, M. (1995). Relationship-based approach to leadership: Development of leader-member exchange (LMX) theory of leadership over 25 years: Applying a multilevel multi-domain perspective. The Leadership Quarterly, 6, 219-247.

Graen, G. B., Novak, M. A., \& Sommerkamp, P. (1982). Effects of leader-member exchange and job design on productivity and job satisfaction: Testing a dual attachment model. Organizational Behavior and Human Performance, 109-131. 
Hair, J., Black, W., Babin, B., \& Anderson, R. (2010). multivariate data analysis (7th ed.). HYPERLINK "https://www.google.com/search?q=Upper+Saddle+River\&stick=H4sIAAAAAAAAAOPgELUz9U3SMkxNi1UAjMNDVIMkrSMMsqt9JPzc3JSk0sy8_P084vSE_MyqxJBnGKrjNTEIMLSxKKS1KJihZz8ZLAwABo J7jdMAAAA\&sa=X\&ved=2ahUKEwi8g6K2kdveAhWICSwKHf1TDCAQmxMoATAPegQICxAH" Upper Saddle River : Prentice Hall.

House, J. (2003). Job stress and social support. Reading Mass: Addison-Wesley.

Janssen, O. (2000). Job demands, perceptions of effort-reward fairness and innovative work behavior. Journal of Occupational and Organizational Psychology, 73, 287-302.

Jennings, J, E. T., \& Ewalt, J. A. (1999). Driving caseloads down: Welfare policy choices and administrative action in the states. A research retreat at the Alan K. Campbell Institute of Public Affairs, Maxwell School, Syracuse University.

Kanter, R. (1988). When a thousand flowers bloom: Structural, collective and social conditions for innovation in organization. In B. M. Staw \& L. L. Cummings (Eds.), Research in organizational behavior (pp. 169-211). Greenwich, CT: JAI Press.

Kmieciak, R., Michna, A., \& Meczynska, A. (2012). Innovativeness, empowerment and IT capability: evidence from SMEs. Industrial Management \& Data Systems, 112(5), 707-728.

Kralewski, D. (2012). Bottom-up, decentralized approach to innovation strategy. In NGEBIS (pp. 55-61).

Lee, J., Min, J., \& Lee, H. (2016). The effect of organizational structure on open innovation: A quadratic equation. Procedia Computer Science, 91, 492-501.

Lin, C., \& Chen, C. (2013). Decentralization, proactive innovation,and mediators: A comparative analysis of cross-level perceptional differences. Asian Journal of Technology Innovation, 21(1), 52-71.

Liu, X., Martineau, T., Chen, L., Zhan, S., \& Tang, S. (2006). Does decentralisation improve human resource management in the health sector? A case study from China. Social Science \& Medicine, 63(7), 1836-1845.

Madanoglu, M., Altinay, L., \& Wang, X. L. (2016). Disentangling the effect of family involvement on innovativeness and risk taking: The role of decentralization. Journal of Business Research, 69(5), 1796-1800.

Martinez-Vazquez, J. (2003). Fiscal decentralization and economic growth. World Development, 31, 1597-1616.

Mayfield, J., \& Mayfield, M. (1998). Increasing worker outcomes by improving leader follower relations [J]. The Journal of Leadership Studies, 5(1), 72-81.

Miedema, A. (2015, March 25). Who is a supervisor? Ontario Ministry of Labour releases guideline.

Mosley, J. D., \& Pietri, P. (2014). Supervisory management. HYPERLINK "https://www.google.com/search?q=Ontario\&stick=H4sIAAAAAAAAAOPgE-

LWT9c3LEkryS63MFHi0M_VNzDNLorXkstOttLPyU9OLMnMz4MzrAqK8ssy85JTAYeqhpY5AAAA\&sa=X\&ved=2ah UKEwi_gbCdmNveAhUFIIsKHepeBeIQmxMoATARegQICRAH" Ontario : Nelson Education.

Mumford, M., Scott, G., Gaddis, B., \& Strange, J. (2002). Leading creative people: Orchestrating expertise and relationships. The Leadership Quarterly, 13, 705-750.

Peeters, M. C., Buunk, B. P., \& Schaufeli, W. B. (1995). Social interactions, stressful events and negative affect at work: A micro-analytic approach. European Journal of Social Psychology, 25, 391-401.

Podsakoff, P. M., MacKenzie, S. B., Lee, J. Y., \& Podsakoff, N. P. (2003). Common method biases in behavioral research: A critical review of the literature and recommended remedies . Journal of applied psychology, 88(5), 879-903.

Popa, S., Soto-Acosta, P., \& Martinez-Conesa, I. (2017). Antecedents, moderators, and outcomes of innovation climate and open innovation: An empirical study in SMEs. Technological Forecasting and Social Change, 118, 134-142.

Power, J. (1998). Decentralization. In J. M. Shafritz (Ed.), The international encyclopedia of public policy and administration (pp. 633-635). Boulder, CO: Westview Press.

Redmond, M., Mumford, M., \& Teach, R. (1993). Putting creativity to work: Effects of leader behavior on subordinate creativity. Organizational Behavior and Human Decision Processes, 55, 120-151.

Richards, G. S., \& Duxbury, L. (2014). Work-group knowledge acquisition in knowledgeintensive public-sector organizations: An exploratory study. Journal of Public Administration Research and Theory, 25, 1247-1477.

Ritzen, M. M. J., \& Soete, L. (2011). Research, higher education and innovation: Redesigning multi-level governance within Europe in a period of crisis. Working Paper, Maastricht uneversity.

Robbins, S. P., Judge, T., \& Breward, K. (2003). Essentials of organizational behavior (Vol. 7): Upper Saddle River: Prentice Hall.

Rodríguez-Pose, A., \& Ezcurra, R. (2011). Is fiscal decentralization harmful for economic growth? Evidence from the OECD Countries. Journal of Economic Geography, 11(4), 619-643. 
Rondinelli, D. A., \& Nellis, J. R. (1986). Assessing decentralization policies in developing countries: The case for cautious optimism . Development Policy Review, 4(1), 3-23.

Rosing, K., Frese, M., \& Bausch, A. (2011). Explaining the heterogeneity of the leadership innovation relationship: Ambidextrous leadership. The Leadership Quarterly, 22, 956-974.

Schroeder, R., Van de Ven, A., Scudder, G., \& Polley, D. (1989). The development of innovation ideas. In A. Van de Ven, H. Angle, \& M. Poole (Eds.), Research on the management of innovation: The Minnesota studies (pp. 107-134). New York: Harper \& Row.

Scott, S., \& Bruce, R. (1994). Determinants of innovative behavior: A path model of individual innovation in the workplace. Academy of Management Journal, 37, 580-607.

Taylor, M. Z. (2007). Political decentralization and technological innovation: Testing the innovative advantages of decentralized states. Review of Policy Research , 3, 231-257.

Tolbert, P. S., \& Zucker, L. G. (1983). Institutional sources of change in the formal structure of organizations: The diffusion of civil service reform, 1880-1935. Administrative science quarterly, 22-39.

Van der Sluis, L. E. (2004). Designing the workplace for learning and innovation: Organizational factors affecting learning and innovation . Development and Learning in Organizations: An International Journal, 18(5), 10-13.

Wang, X. H., Fang, Y., Qureshi, I., \& Janssen, O. (2015). Understanding employee innovative behavior: Integrating the social network and leader-member exchange perspectives. Journal of Organizational Behavior, 36, 403-420.

West, M. A., \& Farr, J. L. (1990). Innovation at work. In M. A. West \& J. L. Farr (Eds.), Innovation and creativity at work (pp. 03-13). New York: John Wiley and Sons.

Yuan, F., \& Woodman, R. W. (2010). Innovative behavior in the workplace: The role of performance and image outcome expectations. Academy of Management Journal, 53, 323-342.

Zheng, X., Diaz, I., Tang, N., \& Tang, K. (2014). Job insecurity and job satisfaction: The interactively moderating effects of optimism and person-supervisor deep-level similarity. Career Development International, 19(4), 426-446. 